\title{
Time and replacement among the Q'eqchi' Maya
}

Tiempo y remplazo entre los mayas q'eqchi'

Temps et remplacement chez les Mayas Q'eqchi'

\section{Paul Kockelman}

\section{(2) OpenEdition}

\section{Journals}

Electronic version

URL: http://journals.openedition.org/jsa/15406

DOI: $10.4000 /$ jsa. 15406

ISSN: 1957-7842

Publisher

Société des américanistes

Electronic reference

Paul Kockelman, « Time and replacement among the Q'eqchi' Maya », Journal de la société des américanistes [Online], Maya times | 2017, Online since 31 December 2017, connection on 20 April 2019. URL : http://journals.openedition.org/jsa/15406 ; DOI : 10.4000/jsa.15406 


\title{
Time and replacement among the Q'eqchi' Maya
}

\author{
Paul KocKelman*
}

\begin{abstract}
Among speakers of Q'eqchi' Maya, replacement (-eeqaj) refers to activities as disparate as house-building, civil-religious elections, vengeance, loans, illness cures, adultery, and namesakes. Such practices involve the substitution of one entity for another entity, insofar as these entities have shared properties, and insofar as they hold a role in an obligatory position. For example, one man may substitute his labor for another man's labor insofar as men have similar degrees of strength and skill, and insofar as a position in a labor-pool must be filled. In this paper, I explore the relation between replacement, as an idea and institution, and 'lived time'. To do this, I offer five different ways of framing temporality (as repetition, irreversibility, roots and fruits, reckoning, and worldview); and I show how replacement may be figured through each of these frames. Along the way, I show how entities caught up in replacement are different from other items of value, such as singularities and commodities; and I offer an entity-centered, as opposed to event-centered, framing of time. [Key words: value, time, replacement, materiality, Maya.]
\end{abstract}

Tiempo y remplazo entre los mayas q'eqchi'. Entre los hablantes de maya q'eqchi', la noción de remplazo (-eeqaj) se refiere a actividades tan diversas como la fabricación de una casa, la elección de cargos civiles o religiosos, la venganza, los préstamos, las curaciones, el adulterio, o los tocayos. Dichas prácticas implican la sustitución de una entidad por otra, en la medida en que estas entidades comparten propiedades comunes, y que cumplen un papel en una posición obligatoria. Por ejemplo, un hombre puede substituirse a otro en un trabajo en la medida en que los dos hombres comparten grados similares de fuerza y habilidad, y que una posición en un equipo de trabajo tenga que ser ocupada. En este artículo, exploro la relación entre el remplazo, entendido como idea e institución, y el "tiempo vivido". Para ello, propongo cinco modos distintos de abarcar la temporalidad (como repetición, irreversibilidad, raíces y frutos, cálculo y visión del mundo); y muestro cómo el remplazo puede concebirse en cada uno de estos marcos. En ese proceso, muestro también cómo las entidades implicadas en la operación de remplazo son diferentes de otros artículos de valor, tales como las singularidades y las mercancías, y propongo una aprehensión del tiempo centrada en las entidades, mas que en los eventos. [Palabras claves: valor, tiempo, remplazo, materialidad, maya.]

* Yale University, New Haven, USA [Paul.kockelman@yale.edu]. 
Temps et remplacement chez les Mayas Q'eqchi'. Pour les locuteurs du maya q'eqchi', la notion de remplacement (-eeqaj) réfère à des activités aussi diverses que la construction d'une maison, les élections civiles et religieuses, la vengeance, les prêts, les cures médicinales, l'adultère ou encore les personnes homonymes. De telles pratiques impliquent la substitution d'une entité par une autre, sous la condition que ces entités partagent des propriétés et remplissent un rôle à une position obligatoire. Ainsi, le travail d'un homme peut-il être substitué par celui d'un autre, dans la mesure où les deux hommes ont des degrés similaires de force et d'habileté, et où une position au sein d'une équipe de travail doit être occupée. Dans cet article, j'explore la relation entre le remplacement, en tant qu'idée et institution, et le « temps vécu ». Pour ce faire, je propose cinq modes distincts de concevoir la temporalité (comme répétition, irréversibilité, racines et fruits, mesure et vision du monde), et je montre comment le remplacement peut s'inscrire au sein de chacun de ces modes. Ce faisant, je mets au jour la façon dont les entités prises dans des opérations de remplacement diffèrent d'items de valeur, tels que les singularités et les marchandises, et je propose d'appréhender le temps à partir des entités plutôt que des évènements. [Mots-clés : valeur, temps, remplacement, matérialité, Maya.]

\section{Introduction}

Among the Q'eqchi' Maya, replacement (-eeqaj) refers to activities as disparate as house-building, civil-religious elections, vengeance, loans, illness cures, adultery, and namesakes. Such practices involve the substitution of one entity for another entity, insofar as these entities have similar quantities of specific qualities, and insofar as they hold a role in an obligatory position. For example, one man may substitute his labor for another man's labor insofar as men have similar degrees of strength and skill, and insofar as a position in a labor-pool must be filled. And an effigy of a sick person may substitute for that person in an illness cure insofar as they have inalienable possessions in common (such as hair and clothing), and insofar as a divinity requires one or the other as compensation.

In this essay I explore the relation between replacement, as an idea and institution among speakers of Q'eqchi' Maya, and five modes of temporality. When one frames temporality in terms of metricality, or patterning, one focuses on the repetition of tokens of common types, as well as the interruption of such otherwise expected tokenings. Temporality as irreversibility (and reversibility) frames processes in terms of their inherent, and potentially alterable, directionality. A third way of understanding temporality foregrounds the roots and fruits of a given event: what other entities and events may be figured as leading to it, or following from it (causally, normatively, inferentially, phenomenologically, or performatively). Temporality as reckoning focuses on the practices through which one determines when an event occurred or how long an event lasted, as well as the processes that regiment such reckoning practices. And temporality 
as worldview focuses on the ways a given community (genre, public, discipline, philosophy, register, etc.) frames the nature of time.

To understand the relation between replacement and temporality, it is useful to call into question the relation between 'lived time' and 'enunciated time'. Heidegger (1996 [1927]) famously distinguished between representations and references. Through the work of Brentano, and the many scholars who followed him (not just Frege and Husserl but also, through Frege, much of analytic philosophy), representations are well known enough: beliefs, assertions, promises, intentions. They are usually understood as a relationship between a mental state (or speech act) and a state of affairs. References (die Verweisungen), in contrast, are the relations things have to each other by virtue of being caught up in practical concerns. For example, the way a nail only makes sense 'in reference to' a hammer, and the ways hammers and nails only make sense 'in reference to' wood and those who work with it (Kockelman 2015). ${ }^{1}$ Somewhat ironically, in his description of this category, which has long constituted a key text for thinking about residence in the world as opposed to representations of the world, and thus the 'lived' as opposed to the 'articulated', Heidegger spent much of his time working through the preposition and case structure of German. For example, one kind of reference (say, wood) is that 'out of which' a hammer is made, another kind of reference (say, a nail) is that 'in terms of which' a hammer is used, another kind of reference (say, a chair) is that 'for which' a hammer is wielded, another kind of reference (say, a user) is that 'for the sake of which' a chair is built, and so forth. For Heidegger, the world was constituted by an ensemble of references; and Dasein was oriented to, and part of, that worlding and worlded ensemble. In introducing this category, Heidegger was arguably linking together Aristotle's account of causes (in the Physics) and his theorization of relations (in the Categories), and then redeploying them in phenomenology-inspired ways.

In the first section of what follows, and pushing off (and away) from Heidegger, I tack between ways of residing in the world, and ways of representing the world, by examining a particular relational noun in Q'eqchi' Maya, focusing on the kinds of practices it is used to represent (or refer to), and the kinds of practices those practice are constituted 'in reference to'. I then show how replacement involves the equivalence of values, and contrast the entities being replaced with more typical objects of economic and critical inquiry: singularities and commodities. In the next section, I detail the way each framing of temporality sheds light on various modes of replacement. And in the conclusion, I discuss the ways replacement itself, as an idea and institution, has changed over time.

1. Do not confuse Heidegger's references (die Verweisungen) with Frege's more famous notion of reference (die Bedeutung), which is, in some sense, the very antithesis. 
Q'eqchi' is a Mayan language spoken in Guatemala by around one million people. The data for this essay come from fieldwork undertaken in a village of Q'eqchi'-speakers, about 800 in number, that is located near Chamelco, in Alta Verapaz, Guatemala. ${ }^{2}$ Most of the families who live in this village practice swidden agriculture, as well as engage in seasonal labor on plantations, poultry husbandry, and itinerant trade. For more than twenty years, starting around 1990, many families also engaged in eco-tourism-acting as hosts and guides for international tourists who came hoping to catch a glimpse of the quetzal bird which lives in the cloud forest that surrounds this village.

\section{Modes of replacement}

Table 1 shows all the adpositions (and many case markers) in Q'eqchi'. While some of these adpositions have temporal readings, as well as spatial readings (such as chiru, 'in front of' or 'before', or chirix, 'in back of' or 'after'), the adposition-eeqaj, 'in place of', has nothing to do with time per se (though, due to its English gloss, it might at first seem spatial). As may be seen, like many other relational nouns, -eeqaj functions not only as an adposition, but also as a relatively unmarked possessed noun. In the rest of this section I will simply enumerate the wide range of activities that were referred to with this word in the village where I undertook my fieldwork. (Appendix A details the various grammatical roles of -eeqaj in this village. Appendix B summarizes the transcription conventions being used.)

A newly elected village mayor is considered the replacement of the previous mayor. Elections - the institutional means for choosing replacements - were held once a year, and any married men in the village could run.

In the religious hierarchy, or cofradia, a newly elected married couple (mertoom) is called the replacement of the previous couple. The cofradia consisted of six couples who were entrusted with caring for the church. Each year a new couple was elected for a six-year tenure, during which time they annually moved up one position in the hierarchy.

In cases where a boy is given the name of his father, he would be considered his father's replacement. This is the one form of replacement that was not frequently practiced-mainly because children named after their parents were thought to be likely to inherit their bad traits.

2. For more information on Q'eqchi' speakers, the Q'eqchi' language as spoken in this village, as well as the anthropology of replacement (as an institution) and the linguistics of-eeqaj (as a relational noun), see Kockelman (2010, 2016), and references therein. Here, for reasons of space, and to avoid repeating the analysis undertaken in this other work, I am offering a simple sketch of replacement in order to show the various ways it is entangled in temporality. 


\begin{tabular}{|c|c|c|c|}
\hline \multicolumn{2}{|c|}{ Adposition } & \multirow{2}{*}{$\begin{array}{c}\text { Gloss of } \\
\text { Adposition }\end{array}$} & \multirow{2}{*}{$\begin{array}{c}\text { Gloss of Noun in } \\
\text { Non-Adpositional } \\
\text { Uses }\end{array}$} \\
\hline Preposition & Relational Noun & & \\
\hline- & $-e$ & $\begin{array}{l}\text { in order to, to, } \\
\text { dative }\end{array}$ & mouth \\
\hline - & $-b{ }^{\prime} a a n$ & because of & \\
\hline - & $-m a a k$ & $\begin{array}{l}\text { because of } \\
\text { (culpability) }\end{array}$ & $\sin$ \\
\hline - & $-i k^{\prime} i n$ & with & \\
\hline - & -uchb'een & $\begin{array}{l}\text { with } \\
\text { (companionship) }\end{array}$ & companion \\
\hline,$- \operatorname{chi}$ & $-u b ' e l$ & beneath & \\
\hline chi & $-u$ & in front of, before & face \\
\hline chi & $-s a^{\prime}$ & inside of & stomach \\
\hline chi & $-e$ & at the side of & mouth \\
\hline chi & $-i x$ & in back of, after & back, fur, bark \\
\hline- & $-e e q a j$ & in place of & $\begin{array}{l}\text { replacement, } \\
\text { substitute }\end{array}$ \\
\hline chi, sa' & $-k^{\prime} a t q$ & at side of, near & \\
\hline$s a^{\prime}$ & $-b^{\prime} e e n$ & on top of & first \\
\hline$s a^{\prime}$ & $-y a n q$ & in between & \\
\hline$s a^{\prime}$ & $-y i$ & in the middle of & waist, tail \\
\hline$s a^{\prime}$ & $-k^{\prime} a b^{\prime} a^{\prime}$ & in the name of & name \\
\hline
\end{tabular}

Table 1 - Adpositions and relational nouns in Q'eqchi' Maya.

One man's vengeful action toward another man is considered the replacement of the other man's prior harmful action. In some sense, this form of replacement was the local equivalent of 'an eye for an eye' or 'a tit for a tat'. (See example (b) in Appendix A.)

One soccer team's tying goal is called the replacement of the other team's previous goal. Like vengeful actions, this involved a kind of settling of scores.

A man who takes another man's place within a labor pool, or fulfills another man's more solitary labor obligations, is called the latter man's replacement. For example, if one man was obligated to work for a second man (because they were reciprocating within a labor-pool), but could not make it because of illness, or a prior obligation, he could send a third man 'in his place'. (See example (a) in Appendix A.) Labor-pooling usually occurred with arduous 
or time-consuming practices such as the clearing and planting of agricultural fields, and house-building.

The money returned to another as the settling of a loan is called the replacement of the originally loaned money. Loans were usually made between members of an extended family, were relatively small in size, and accrued no interest. For example, a man might lend his daughter-in-law money to buy household supplies while her husband was away working on a plantation.

In cases where a person has suffered 'fright' (xiwajenaq), as brought on by a moral breech such as forgetting to pray or deprecating corn, they could bury a replacement, or effigy, of themselves in the place where they were frightened. Only in this way, would the person not fall ill, insofar as the agency that frightened them accepted the effigy as a replacement for their health or well-being (see example (c) in Appendix A). These effigies consisted of tree-sap, formed in the shape of a person, and mixed with various inalienable possessions of the sick person: fingernails, hair, and clothing. ${ }^{3}$

A man who slept with another man's wife is called 'his replacement'. I don't have any data on this, but it was a source of anxiety in the village as many men worked seasonally on plantations, and so left their wives and families for months at a time.

A newly built house is called the replacement of the owner's old house. Besides referring to houses for humans, replacement was also used to refer to houses for domestic animals: for example, chicken coops, turkey runs, and pig pens.

Finally, there was a large number of other more quotidian forms of replacement, which involved the equivalence of everyday objects of utility, rather than human actors and their activities per se. For example, after I knocked my coffee cup onto the floor, my host told her son to bring me 'its replacement'. Or, when the gas in their lamp was all used up, a man suggested to his wife that they go get 'its replacement'. In this way, the accidental loss or normal provisioning of a 'necessity' entailed a replacement. Such processes often involved the most stereotypic of use-values: a bag of salt, a set of batteries, a pair of rubber boots, and so forth. Table 2 summarizes these practices.

1) A newly elected village mayor is called the replacement of the previous mayor.

2) In the religious hierarchy, or cofradia, a newly elected married couple (mertoom) is called the replacement of the previous couple.

3) In cases where a boy is given the name of his father, he would be considered his father's replacement.

4) One man's vengeful action toward another man is called the replacement of the other man's prior insulting or harmful action.

3. Kockelman (2010, chapter 2) treats inalienable possession, and illness cures, at length. 
5) One soccer team's tying goal is called the replacement of the other team's previous goal.

6) A man who took another man's place within a labor pool, or fulfilled another man's more solitary labor obligations, is called the latter man's replacement.

7) The money returned to another as the settling of a loan is called the replacement of the originally loaned money.

8) In cases where a person has suffered fright (xiwajenaq, or 'susto'), as brought on by a moral breech such as forgetting to pray or deprecating maize, they could bury a replacement, or effigy, of themselves in the place where they were frightened. Only in this way, could the person not fall ill, insofar as the agency that frightened them accepted the effigy as a replacement for the person's health.

9) A man who slept with another man's wife is called his replacement.

10) A newly built house is called the replacement of the owner's old house.

11) Most generally, the accidental loss or normal provisioning of a necessary item entails a replacement. Such processes often involve the most stereotypic of use-values: a bag of salt, a lantern's worth of oil, a set of batteries, a pair of rubber boots, and so forth.

Table 2 - Key referents of the word replacement (-eeqaj).

\section{Replacement, equivalence, and value}

Replacement may thereby involve: 1) replacing a person in some kind of office: mayor, cofradia, namesake; 2) settling some kind of score: revenge, soccer goals, loans, labor pools, illness cures; and 3) replenishing a worn out or used up good: houses, batteries, and use-values more generally. In all such cases, entities and actors within certain domains must have a replacement (lest their role go unfulfilled, their function stay unserved, or some imbalance be maintained); and other entities may substitute for such entities (insofar as they are judged relatively equivalent in regards to their quantities of particular qualities).

As such, replacement involves the equivalence of values. And, in particular, it involves a mode of equivalence that sits in-between two more famous modes of equivalence: singularities and commodities. See Figure 1. In the case of singularities, we have questions like: are these instances of the same individual? For example, is this gun the same gun that was used to assassinate Lincoln? Is that painting the one that was actually painted by da Vinci, or merely a copy? Here we have questions as to the nature of aura, and the value of entities and events that are one-of-a-kind. In the case of commodities, we have questions like: are these two distinct use-values (say, a bolt of cloth and a bushel of wheat) equivalent, and why? Here we have questions of underlying effort, of supply and demand, of utility trade offs, of exchange value in relation to use-value. Replacement, in contrast, while sometimes treated like commodities (e.g. loans) or singularities (i.e. name-sakes), is usually somewhere outside or in between. 
Loosely speaking, rather than asking whether these are instances of the same individual, or use-values with the same exchange value, we ask whether these individuals are versions of the same use-value. That is, does each one have more or less the same physical qualities, or underlying capacities, in more or less the same quantities.

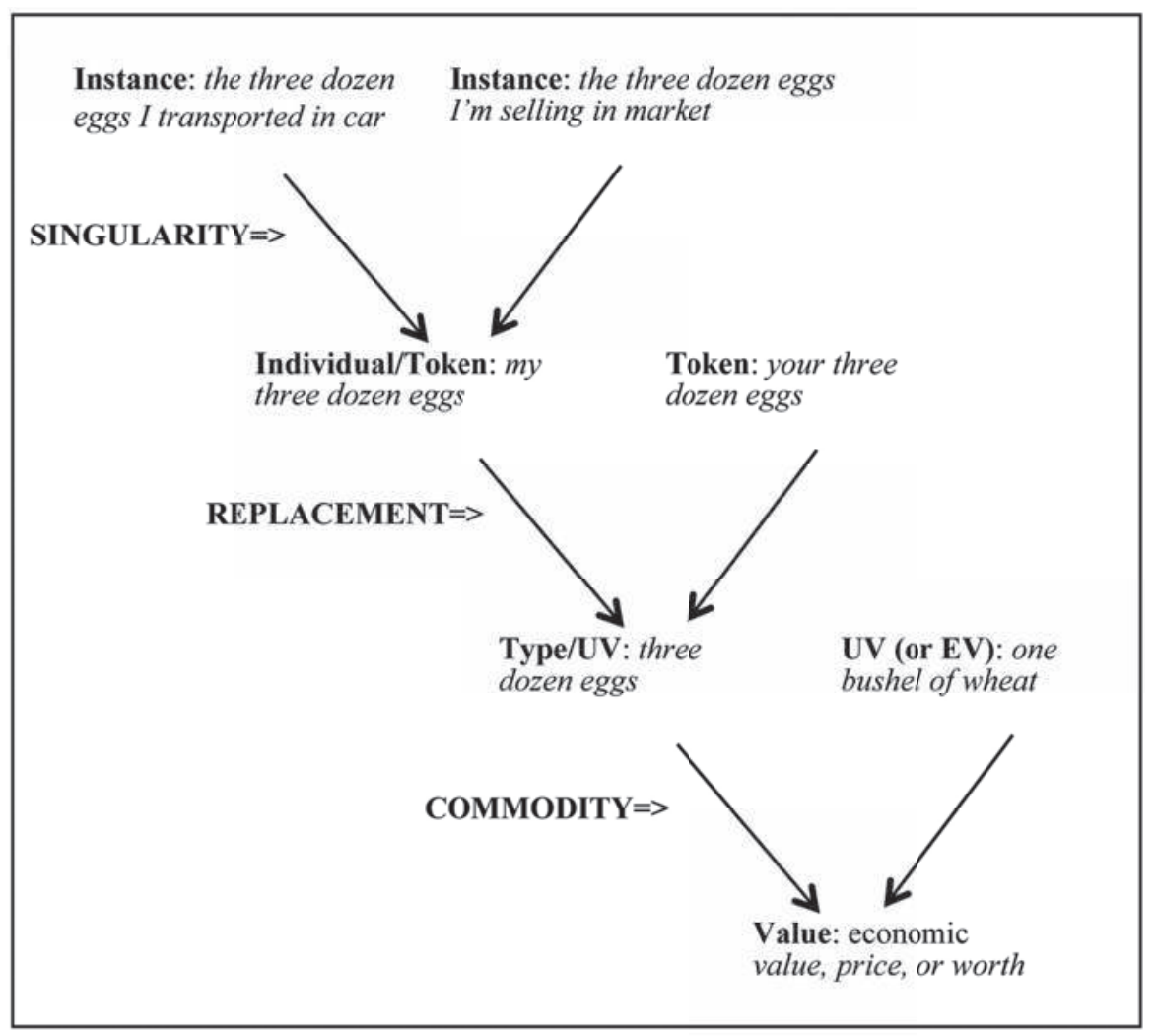

Fig. 1 - Three kinds of equivalence: singularities, replacements, commodities.

In other work (Kockelman 2016), I have detailed these qualities and quantities, showing how they are understood in local ontologies, so I will not review those arguments, or present that evidence, here. But it should be noted that whether or not one entity can replace another entity can be a contentious issue, especially in the case of labor-pooling. For example, when can a boy replace a man? Can a woman ever replace a man? What happens when men opt out of labor-pooling in favor of cash payment? And what happens when some men are no longer considered replaceable, insofar as they have specialized skills 
that are not widely distributed? More generally, what are the metrics used to determine whether individual entities are similar enough in quantity and quality? What are the salient qualities people attend to? And how do they assess the relative intensity of such qualities? In particular, how do villagers judge the relative commensurability of otherwise disparate entities and actors across such a wide range of domains? I will return to these issues in the conclusion.

One could also spend a lot of time on this question of must - the fact that houses must be rebuilt; loans must be paid; scores must be settled; labor must be returned. In many cases, such modes of obligation and necessity are a matter of course: they were relatively tacit requirements that nobody would ever dispute or even discuss. Indeed, like the units themselves, many of these needs were presupposed, and ultimately naturalized, by the domestic mode of production and its conditions of renewal: replacing a house, raising children, sowing corn, partaking in cofradia service, and electing mayors. In other cases, such as those we just discussed in the case of labor-pooling, there were transformations underway in local understandings of what is obligatory or necessary. In any case, it is useful to compare such modes of obligation with those discussed by Mauss in the case of gift-giving: the obligation to give, receive, and reciprocate. Or with those underlying contract (obliging one to undertake terms that were freely committed to). Or even with those underlying Weber's conception of the Protestant ethic: the obligation, or duty, to increase one's capital. In contrast, the key obligation underlying replacement was nothing other than the systematic provisioning of social life. In some sense, then, the institution of replacement constitutes an economy - in Karl Polanyi's sense - in which the underlying value is not riches, or even reciprocation, but rather replenishment.

\section{The temporality of replacement}

The inherent temporality of singularities and commodities has long been argued and studied (Benjamin 1968; Marx 1967 [1867]; inter alia). Just as singularities seem to trace individual biographies and collective histories, commodities have been linked to abstract labor time, and capitalist modes of temporality. In what follows, by way of contrast, I focus on the temporality of replacement. I characterize five interrelated ways that events and experiences may be framed in temporal terms (Kockelman 2010; Kockelman and Bernstein 2012); and I show how each kind of frame comes to the fore in various modes of replacement. See Table 3. Crucially, any entity or event can be framed in temporal terms in numerous ways. The claim, then, is not: here are necessary and sufficient conditions for being 'temporal', and here is why various modes of replacement satisfy such conditions. Rather, the claim is: here are some clear and useful ways of framing 'temporality', as ideal types, each of which may be used to better understand the distinctiveness of replacement as an idea and institution. 
By temporality as repetition (and interruption), I mean a mode of understanding, practical or theoretical, that frames entities or events as periodic instances of the same, and thus the repetition of tokens of a common type. From Hesiod to Jakobson (1990).

By temporality as irreversibility (and reversibility), I mean a mode of understanding, practical or theoretical, that frames processes in terms of their inherent directionality. From Boltzmann to Serres (2007 [1980]).

By temporality as reckoning (and regimentation), I mean modes of understanding, practical or theoretical, that frame processes in terms of their when and their how long. William Bull (1960), in particular; and see also Kockelman and Bernstein (2013).

By temporality as roots and fruits, I mean a mode of understanding, practical or theoretical, that frames an entity or event in terms of what led to it or leads from it. James (1975), Husserl (1999) on retention/protention, Austin (2003) on appropriateness/effectiveness, etc.

By temporality as worldview, I mean of mode of understanding that is oriented to time as such: what is time, what is the nature of temporality.

Table 3 - Five ways of framing temporality.

By temporality as repetition (and interruption), I mean a mode of understanding, lived or enunciated, that frames events as periodic instances of the same, and thus foregrounds the repetition of tokens of a common type. Not just the natural phenomena that undergird days, months, and years; but also rush hours, migrations, and migraines. Not just swings of pendula and ticks of clocks, but also drips of faucets and turns of screws. Crucially, interruption is the flip side of repetition: prior events create expectations that are not just sated through future events, but also frustrated. Anomalous events and atypical tokens are thus just as important as run-of-the-mill types. And so, affective modalities like frustration and surprise, as much as satiation and expectation, are important ways such temporal orientations are experienced.

As we just saw, many modes of replacement involve the periodic renewal of particular goods: not just cofradía hierarchies, mayor elections, and namesaking; but also the replacement of any use-value that wears out or is used up. Each kind of 'good', each entity or actor subject to replacement, whether it be a mayor or a machete, has its own characteristic time-scale. Some of these scales are relatively pre-ordained, precise, and predictable (for example, an annual election of a major, a six-year term of a cofradia couple). And some of these scales are relatively token specific and fuzzy (for example, how long does it take for a certain type of house to wear out, or when can a certain kind of machete no longer be sharpened). Even the modes of replacement that involve score-settling have their own temporal scales. For example, within what time-frame should an injustice be repaid (typically as soon as possible)? When should a labor-obligation be fulfilled (usually within the same season)? How soon can we undertake an illness 
cure (when the requisite inalienable possessions have been collected)? And all such goods have their particular tensions in the interims. For example, there are worries about who will be elected next, ceremonies of leave-taking and inducting, questions of fairness and hanging obligations, worries about having waited too long, and so forth. In short, there is a kind of temporal meter, or poetics, that organizes the periodic movement from a particular entity to its replacement. Any such replacement may satisfy an expectation or frustrate it, with characteristic tensions, often experienced through such affects. Different kinds of replacements involve not only different kinds of meters, but also different ways of violating meters: different ways of being too soon or too late, too rushed or too delayed.

To offer a more extended example, there are two kinds of griddles $\left(k^{\prime} i l\right)$ that are used for making tortillas in the village: earthenware griddles (ch'och' $k$ ' $i l$ ) and metal griddles ( ch $\left.^{\prime} i i_{c h}{ }^{\prime} k^{\prime} i l\right)$. Such griddles might at first be considered 'substitutable goods' by economists (in the sense that one can replace the other in a given task, such that if the price of one increases the demand for the other increases). According to the Q'eqchi', however, earthenware griddles tend to consume more fuel and produce tastier tortillas than metal griddles. Moreover, earthenware griddles are often passed down from mothers to daughters as heirloom items (and so, strictly speaking, are more like irreplaceable goods, or 'singularities'). In contrast, metal griddles are bought in a store, and are easily and often replaced (usually after a year or two of use). In this way, both kinds of griddles have different temporal scales built into their circulation (earthenware, on the order of a generation; metal, on the order of a year). Both kinds of griddles involve different kinds of ownership and transaction (earthenware are inherited, metal are purchased). And both kinds of goods are used on different kinds of time-scales. The metal griddles are typically used three times a day, to make tortillas for members of the immediate family, on relatively quotidian occasions. In contrast, the earthenware griddles are used much less frequently, and only for key festivals involving more distant kin (Christmas, saints days, weddings, baptisms, and so forth). Indeed, they were used to celebrate relatively 'repeated' events, characteristic of rituals. In short, the temporal meters underlying the replacement of two ostensibly substitutable goods, in regards to use as much as replacement, were wildly divergent; yet both were attuned to key modes of village temporality - in effect, the sacred and the profane.

By temporality as irreversibility (and reversibility), I mean a mode of understanding that frames processes in terms of their inherent directionality. For example, does one understand the future as relatively open to human intervention, and the past as closed? Does one foreground the impossibility of exact repetition, and the importance (and loss) of aura? Does one highlight the production of heat, disorder, or decay? Does one attend to the tapping out of potentials, the degradation of gradients, and the ways systems settle down to equilibria? When 
is one forced to contend with such thermodynamic realities? Conversely, under what conditions can one ignore such directionalities (for example, times of great surplus or eras of low population density)? Crucially, such a temporal framing also foregrounds the agents that lead to such directionalities. For example, parasites, entropy, noise, friction, degradation, middle men. It foregrounds the various safeguards we have against such agencies. For example, refrigerating, lubricating, and shoring up. And it foregrounds the various processes that seem to locally circumvent such tendencies, and thereby give rise to order: not just restocking and resupplying, but also evolution and emergence more generally.

For example, the most common forms of replacement involve processes in which a stereotypic good, a 'use-value', wears out due to entropic processes (say, the rotting of the walls and roof of a house), or is used up through consumptive practices (for example, batteries, oil, salt, and sugar), or is taken by third-agents (a predator that kills one's chickens, a thief that steals one's flashlight). And so, there is an orientation to the inherent leveling of time, and to the rebuilding and restocking of that which has been leveled down. Recall our last example: earthenware griddles last much longer than metal griddles; in part, because metal griddles are used more often and, in part, because they are subject to irreversible processes on much faster time-scales. Some modes of replacement are even oriented to the decay of human life per se-the replacement of older people with younger people. Finally, other modes of replacement involve relatively reversible processes - settling scores (soccer, justice), repaying debts (loans, labor-pools), and zeroing accounts. In such cases, values - and, in particular, valuable resources - come to the fore: that which is consumed in use, and/or that which takes effort (labor, time, energy, and other resources) to restock, return, renew, or repay.

Houses, for example, were one important site in which this modality of temporality was often foregrounded. In part, this was because older houses that had been abandoned (after their replacements had been built) became mnemonics of village history: wili' li oqech aran. kiwan li rochoch qawa' Alejandro. kikam. ab'anan toj wan li rochoch lix rab'in chiru li tzuul aran ('See those posts there [part of the framing of a house]. That was where Don Alejandro used to live. He died, but his daughter's house still sits on the hill over there [pointing]'). In part, this was because some villagers said they could judge the wealth and virtue of a house's owner by its state of decay: the more money one had, the more frequently one would replace one's house; and the more industrious one was, the more one would care for one's house; and hence the less run down one would let it become. (Other villagers, in contrast, and perhaps more charitably, used similar indices to infer that times were tough, or that a family was hard up.) In this way, just as an abandoned and decaying house became an index of village history, the relative decay of one's current home became a sign of social 
status, labor prowess, or economic difficulties. Traces of entropic processes are just as important and pervasive as evidence of energetic pathways. And the degree to which one countered the second law of thermodynamics, and hence took issue with the inherent directionality of time, so to speak, constituted a local index of relative wealth and workmanship, as well as a sign of difficult circumstances and personal struggles.

By temporality as reckoning (and regimentation), I mean a mode of understanding that frames processes in terms of their when and their how long (as well as their how fast and how often). Here go instruments like clocks and calendars, and categories like tense and aspect, not to mention metronomes and pacemakers. Reckoning typically presumes privileged points (the speech event, the birth of Christ, armistice) and privileged periods (day, second, swing). Such privileged points and periods are used as grounds relative to which the when and how long of other, less privileged points and periods are figured. For example, when one says, $x k$ 'ulun oxejer, or 'he arrived three days ago', the speech event is the privileged point relative to which the when of his arrival is reckoned; and a day is the privileged period used to reckon how long before the privileged point his arrival occurred. See Table 4a. Similarly, when one says, xkam chirix lix kub 'ilha' aj Lu', or 'she died after the baptism of Pedro', the baptism is the privileged point relative to which the event of her death is reckoned. Crucial here are the social scales that determine with whom, and in what context, one can presume a certain point or period as a privileged ground; as well as the social scales that come into being when a certain point or period gets publically figured, and so can be subsequently used as a privileged ground by members of the public constituted by that figuring. For example, one can only use someone's baptism as a privileged point of reckoning with an interlocutor who knows who is being talked about and when their baptism occurred. Reciprocally, once one has reckoned the 'when' of an event (relative to such a privileged point), that when can itself become a privileged point: chirix lix kamik mas ra xk'ul lix b'elom, or 'after her death her husband suffered greatly'. See Table 4b, and see Table $4 \mathrm{c}$ for examples showing the extension of the system.

\begin{tabular}{|c|c|}
\hline \multicolumn{2}{|c|}{ hoon (today), anaqwan (now) } \\
\hline ewer (one day ago, yesterday) & hulaj (in one day, tomorrow) \\
\hline kab'ajer (two days ago) & $\boldsymbol{k} \boldsymbol{a} \boldsymbol{b}^{\prime} \boldsymbol{e j}$ (in two days) \\
\hline oxejer (three days ago) & oxej (in three days) \\
\hline kwehejer (four days ago) & $\boldsymbol{k} \boldsymbol{w e h e j ~ ( i n ~ f o u r ~ d a y s ) ~}$ \\
\hline hoob'ejer (five days ago) & hoob’ej (in five days) \\
\hline
\end{tabular}

Table $4 \mathrm{a}$ - Temporal adverbs (privileged period is day, privileged point is usually speech event (=Es). 
1) $x-$ O-kam chi-r-ix li-x kub'ilha' aj Lu'

Perf-Abs(3s)-die Prep-Erg(3s)-after Dm-Erg(3s) baptism SD Pedro

'she died after the baptism of Pedro'

(Pedro's baptism is a privileged point relative to which timing of her death is reckoned)

2) chi-r-ix li-x kam-ik mas ra $x-\emptyset-x-k$ 'ul li-x b'eelom

Prep-Erg(3s)-after Dm-Erg(3s) die-Nom very painful Perf-Abs(3s)-Erg(3s)receive $\mathrm{Dm}-\operatorname{Erg}(3 \mathrm{~s})$ husband

'after her death her husband suffered greatly'

(her death is a privileged point relative to which timing of her husband's suffering is reckoned)

Table $4 \mathrm{~b}$ - Temporal reckoning with adpositions.

1) Event Reckoned relative to calendrical event (Ec):

chi-r-u li chihab' mil nove-syent sesent li $x$-b'een poyanam $\boldsymbol{k}-\boldsymbol{e}$-hulak aran

Prep-Erg(3s)-face Dm year 1000 9-100 60 Dm E(3s)-first people Inf-Abs(3p)-arrive there 'during the year 1960 the first people arrived there'

2) Event Reckoned relative to narrated event (En), itself reckoned relative to calendrical event (Ec):

chi-r-ix li-x hulaj-ik $k-\emptyset-e^{\prime} x-y i i b '$ chixjunil li ochoch

Prep-Erg(3s)-behind Dm-Erg(3s) arrive-Nom Inf-Abs(3s)-Erg(3p)-make all Dm house 'after their arrival, they built all the houses'

3) Event reckoned relative to speech event (Es):

$x$ - -yaj-er hoob'ejer

Perf-Abs(3s)-sick-become five-days-ago (see Table 4a)

'he fell ill five days ago'

4) Event reckoned relative to narrated event (En), itself reckoned relative to Speech event (Es):

chi-r-u li-x yaj-ik, mas kaw-Ø-Ø

Prep-Erg(3s)-face Dm-Erg(3s) sick-Nom very strong-Pres-Abs(3s)

'before his illness he was very strong'

Table $4 c$ - Other types of privileged points (Ec, En, Es), and their discourse enchaining.

Many forms of replacement presumed widely privileged periods: the election cycle, or year, the person cycle, or generation. And moments of renewal often constituted privileged points for reckoning: after the election, during the ceremony, when she fell sick, right before I paid him, just after our son was born. Indeed, the most quotidian forms of replacement constituted not eventcentric points and periods, but entity-centric points and periods. In some sense, each and every use-value as a type could constitute a privileged period (how 
long it usually takes to wear out, or use up); and every use-value as a token could constitute a privileged point (when the last one wore out, or when was it last renewed, and hence when might the current one wear out, and when might it need to be renewed again). For example, 'when those batteries wear out (privileged point), replace them with the ones I left under the bed'. The public that reckoned with such privileged points and periods could be greater or smaller in scope. Sometimes the entire village could presume one and the same privileged point or period (say, an election cycle); sometimes only immediate families involved in an illness cure could (say, when the victim first took ill); sometimes all the men involved in a labor pool could presume the same privileged point or period (say, the last time they collectively built a house); sometimes just the two parties of a loan (say, when the advance was given).

It is worth offering one more example of temporality as reckoning insofar as it overlaps with temporality as repetition (and interruption) and temporality as irreversibility (and reversibility).

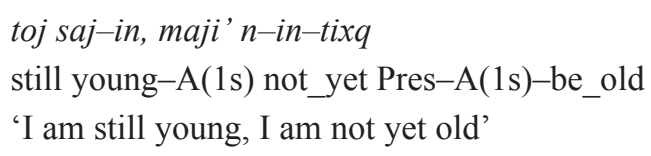

Here we have a woman reporting the speech of her husband (who was 28 years old at the time). When she had asked him to join the cofradia as a couple, he had replied 'I am still young, I am not yet old'. This became a point of contention for the couple: the woman wanted to join the cofradia (because it was a key mode of replacement that women could partake in, one that offered entry into extensive modes of village-wide and weekly sociality); whereas the man took participation in the cofradia as a sign of more traditional ways, and hence best left to older couples. In particular, the man had wanted instead to run for mayor - a different mode of replacement (that only men could partake in), and one for which younger and younger men were more and more often being recruited. Rather than knowledge of traditional ways, high competence in Spanish and extensive implication in extra-village social relations became key requirements for election. Crucially, in articulating his reasons for not wanting to join, the man used two temporal adverbs: toj (similar in function to 'still') and maji' (similar in function to 'not yet'). As may be seen in Table 4d, such morphemes form part of an important set of adverbs. Each such adverb is used to indicate that the beginning (or end) of a narrated event occurred before (or after) a reference event. Such reference events constitute privileged points. In this case, the reference event was the (reported) speech event. In other cases, the reference event may be another narrated event, for example, in an utterance like, naq xinhulak sa' poopol toj wankeb' li winq ('when I arrived at the courthouse, the men were still there'). Here, the event of the men being at 
the courthouse (and its onset or offset) is the narrated event, and the event of arriving at the courthouse is the narrated reference event (which establishes a privileged point precisely by referring to one). In this way, speakers not only use privileged points and periods to reckon, they also establish what counts as a privileged point or period, and thereby help regiment their own and others' processes of reckoning.

\begin{tabular}{|l|l|}
\hline $\begin{array}{l}\boldsymbol{a} \boldsymbol{k}(\text { already) } \\
<=\mid= \\
\text { onset }(<) \text { of narrated event }(==) \text { before } \\
\text { reference event }(\mid)\end{array}$ & $\begin{array}{l}\text { maji' (not yet) } \\
\mid<== \\
\text { onset }(<) \text { of narrated event }(==) \text { after } \\
\text { reference event }(\mid)\end{array}$ \\
\hline $\begin{array}{l}\text { toj (still) }=\mid=> \\
\text { offset }(>) \text { of narrated event }(==) \text { after } \\
\text { reference event }(\mid)\end{array}$ & $\begin{array}{l}\text { ink'a' } \text { chik (no longer) } \\
==>\mid \\
\text { offset }(>) \text { of narrated event }(==) \text { before } \\
\text { reference event }(\mid)\end{array}$ \\
\hline
\end{tabular}

Table $4 \mathrm{~d}-$ Temporal adverbs (where reference event is privileged point, itself usually either Es or En).

By temporality as roots and fruits, I mean a mode of understanding that frames an entity or event in terms of what led to it or follows from it. For example, one and the same speech act is appropriate in context (roots) and effective on context (fruits). One and the same action may be an interpretant of a prior sign, and a sign that will lead to a subsequent interpretant. The same event may be understood as an effect of a prior cause, or a cause that will give rise to a subsequent effect. As discussed in Kockelman (2010), for example, the interjection chix ('yuck, ugh') is not just an exclamation that is 'caused by' the perception that matter is out of place (for example, a woman might say it after seeing that a chicken has shat near her hearth fire). It is also an imperative that 'causes' another agent to undertake an action (for example, the woman's son, upon hearing his mother say chix, might go fetch a shovel to clean up the mess). Similarly, and as just seen, a decaying house may simultaneously function as both symptom and herald. That is, it not only indexes past events, and the character of actors implicated in them; it also indexes future worlds, and the possible actions of those who will inhabit them. This framing of temporality foregrounds all the ways in which any now is thick with its conditions and consequences, be these discursive, semiotic, causal, inferential, phenomenological, and so forth.

Finally, by temporality as worldview, I mean of mode of understanding that is oriented to time as such: what is time, what is the nature of temporality. Here go Mayan myths recounting the marriage of the sun and the moon (and the creation of the cosmos), as well as claims from theoretical physics (the 
laws of thermodynamics, special relativity), as well as classic understanding of propitiousness (when should we harvest, what is a lucky month to be born), as well as philosophical understandings of temporality (is time abstract or concrete, circular or linear, progressing, or devolving). For example, one widespread and, arguably erroneous worldview is often articulated by critical theorists: that modern modes of temporality are 'abstract', or 'empty and homogeneous', whereas premodern modes of temporality are 'concrete'. Hopefully, as per the last set of examples, the reader should now see that most of us, and not just speakers of Q'eqchi', reckon time by reference to concrete events and entities, insofar as they constitute privileged points and periods: yesterday and tomorrow, during spring break, and after the war, in $200 \mathrm{BC}$ and during the full moon, after the holidays, at low tide, when we still lived in Santa Fe, in the wake of September 11th, before the Pleistocene, during the Anthropocene, and so forth. Finally, it cannot be emphasized enough that the very framework being developed and deployed in this essay ('five ways of framing time') is itself a kind of worldview - a set of assumptions, themselves inherently timebound, and probably quite provincial, about what makes some experience or phenomenon relatively 'temporal'.

\section{Conclusion}

I will now put together temporality as roots and fruits, and temporality as worldview, in order to offer a few final thoughts about the temporality of replacement. As laid out above, replacement may be understood as an ensemble of assumptions as to the equivalence of various entities: what requires a replacement; what can count as a replacement; and what are the conditions of possibility for such requirements. Such assumptions, while not articulated, or made explicit as such, nevertheless constitute a set of beliefs that are committed to in practice, via relatively habitual, as well as relatively one-of-a-kind, actions. In this way, they constitute an important part of one's worldview (ideology, ontology, mentality, cosmology, habitus, culture, etc.), a part which, while not about time per se, is deeply entangled in temporality, in all the ways just shown. To return to Heidegger (and Frege), while such assumptions may not refer to or directly represent temporality, they are certainly constituted 'in reference to' it.

Crucially, such assumptions have roots and fruits. On the one hand, they count as a condition for interpretations - for example, judgments as to who can replace whom in what context. They thus lie at the root of many kinds of practical decisions. On the other hand, they are themselves a consequence of interpretations - for example, they came about as a function of a group's experience in the world, and the way that group made sense of such experience. In short, replacement constitutes a kind of worldview (however partial, implicit, inconsistent, ephemeral) that is, in part, about time; and that worldview itself, 
whatever its particular contents at any particular moment, has roots in past events, and bears fruit in future events (and so transforms over time).

So let me conclude by highlighting three key time scales on which such assumptions have transformed, or are in the process of transforming. That is to say, let me conclude by outlining the temporality of such assumptions about temporality. For my purposes, and to vastly simplify, three scales are particularly relevant. First, there are processes on the order of thousands of years (for example, Mesoamericanwide versus Mayan-specific, pre-conquest versus post-conquest, pan- or protoMayan versus particular to the Quichean-branch). Second, there are processes on the order of hundreds of years (for example, speakers of Q'eqchi' pre- and post-sixteenth-century reductions, or pre- and post-19th-century modernization). And finally, there are processes on the order of decades (for example, pre- and post-civil war, or pre-and post-ecotourism boom).

In regards to the longest scale, practices somewhat similar to replacement, and words somewhat similar to -eeqaj, have been documented in other Mayan communities - albeit in a much more circumscribed fashion. For example, Carlsen and Prechtel (1991) argue that the Tzutujil word $k$ 'ex refers to the replacement of older persons with younger equivalents. They refer to this as "making the new out of the old" and "reincarnation," and they characterize it as "relating to the transfer, and hence continuity, of life" (26). And Mondloch (1980), working with the Mayan language Quiche, has discussed the use of the word k'e?s in relation to naming practices, describing it as a "social mechanism for replacing the ancestors" (9). Similar themes have been echoed by other Mayanists working in Highland Guatemala. While I have no data on the historical transformations of the word -eeqaj, in meaning or in form, it may be the case that reincarnation - and the replacement of persons more generally - is the primary and more widespread usage. If so, it would indicate that the replacement of people - not only in namesaking, but also perhaps in civil-religious elections (as mayor and cofradia members) and perhaps illness cures - is the more basic process.

In regards to the middle scale, it should be remembered that what passes as a local cultural order may have its origins in a colonial imposition. And what passes as a natural process of renewal may have its origins in the novel demands of capital. And so, while such religious-cosmological interpretations are important, it is also worthwhile maintaining a more worldly interpretation. For example, it has been suggested by Wilk (1991) that labor-pooling among the Q'eqchi' - which was shown to be one of the most important institutions involving replacement - may be a response to colonial forms of labor extraction (and perhaps pre-conquest forms of tribute-taking). That is, originally it was the state or coffee plantation that one owed labor to. And, if one couldn't fulfill this obligation, one had to send a replacement. In short, if the first scale 
pushes us towards rethinking replacement in terms of reincarnation, this scale pushes us towards rethinking replacement in terms of exploitation.

In regards to the final scale, villagers joined forces with an ecologically-minded NGO in the 1990s and started an eco-tourism project (Kockelman 2016). The money generated from this venture was supposed to be an incentive for villagers to stop their 'slash and burn' agriculture, and thereby preserve the cloud forest that surrounds this community, along with the endangered avifauna that reside there. In so doing, many villagers were 'capacitated' to engage in a wide variety of novel and specialized forms of labor: monitoring key species, hosting and guiding tourists, acting as extensionists to other villages, and so forth. Simultaneously, the NGO was giving out awards and certificates to such villagers, and thus highly visible signs of their new, hard-earned, and unique capacities. Such villagers began to drop out of the system of replacementgiving up labor-pooling in favor of cash-payment, and constructing new kinds of houses with no local equivalents. That is, whereas replacement was once a condition for local values (constituting, as we saw, the systematic provisioning of social life, and hence replenishment in an extended sense), irreplaceability was becoming, for those villagers implicated in the eco-tourism project, a value in itself.

\section{Appendix A - Grammatical roles of -Eeqaj}

The following three examples show utterances in which-eeqaj was used to describe a certain kind of replacement, functioning either as an adposition (a), a possessed relational noun (b), or an unpossessed noun (c).

\section{a) $x-\varnothing$-x-taqla raj li $r-$ al $r$-eeqaj}

Neg Perf-Abs(3s)-Erg(3s)-send CF Dm Erg(3s)-son Erg(3s)-replacement 'he would have sent his son in place of him'

In this utterance, a woman was describing how another man would have to send his son 'in his place', or as his replacement, but did not. Here the kind of work in question was guiding eco-tourists (who came to see the quetzal bird). While it was frowned upon to send one's son instead of going oneself, villagers often did it when they had other, more pressing tasks to take care of. ${ }^{4}$

4. Some speakers also use -uuchil to refer to replacements involving labor. For example, upon showing up at a worksite in place of someone who was expected to work, one may say: $x$-in-chal cho' $q$ r-uuchil (Perf-A(1s)-come as $\operatorname{Erg}(3 \mathrm{~s})$-replacement), or 'I came as his replacement'. 
b) $t-\varnothing_{j}-i n-k$ 'e $\left[r_{i}-e e q a j[l i k \text { 'aru } x-\varnothing-a a-b \text { 'aanu } w \text {-e ewer }]_{i}\right]_{j}$

Fut-Abs(3s)-Erg(1s)-give Erg(3s)-replacement Dm what Perf-Abs(3s)$\operatorname{Erg}(2 \mathrm{~s})$-do $\operatorname{Erg}(1 \mathrm{~s})-$ Dat yesterday

'I will give (to him) the replacement for what he did to me yesterday'

In this utterance, a man was describing how he would seek revenge for the insult another man gave him the day before. As indicated by the subscript (i), the third-person, singular ergative possessor prefix on -eeqaj cross-references the entire nominalized clause ('what he did to me yesterday'). Finally, as noted by the subscript (j), the entire noun-phrase headed by -eeqaj is itself crossreferenced by the 3rd-person, singular absolutive affix on the verb k'ehok (to give). That is to say, it is what is being given. In this example, then,-eeqaj is not being used as an adposition, for the entire clause headed by it is an argument of the main verb.

c) a'an jun li eeqaj ajwi'

Pro(3s) one Dm replacement also

'that is a (kind of) replacement as well'

This example of a non-possessed use of -eeqaj occurred in an ethnographic interview. A man had been enumerating different types of replacement, and had just discussed the kind that occurs in illness cures, when one buries an effigy of oneself in the ground as part of the actions necessary to recover one's health. Having described such practices, he finished with this utterance.

\section{Appendix B - Transcription conventions}

Erg(1s) ergative case, first-person singular (and similarly, for other combinations)

$\operatorname{Abs}(2 \mathrm{p})$ absolutive case, second-person plural (and similarly, for other combinations)

Dm determiner

CF counterfactual

Nom nominalizer

Q'eqchi' verbal predicates involve a paradigm with six forms, most of which are closely linked to temporal dynamics:

nak- $\quad$ so called 'present-tense', really unmarked, habitual aspect

$x-\quad$ so called 'recent past', really perfect aspect 
ki- $\quad$ so called 'remote past', really perfect aspect and inexperienced evidential (typically used to recount myths, to describe events one didn't personally experience, and/or to indicate that one's claim is a strong inference; that said, there is a lot of variation among speakers)

ta- $\quad$ so called '(recent) future', more likely prospective aspect

chi- sometimes called 'remote future', really optative mood, used in polite imperatives

$m i-\quad$ negative optative mood, negative imperative

$\varnothing$ - $\quad$ imperative mood

Finally, there is a very productive derivational suffix $-\boldsymbol{i} \boldsymbol{k}$, that usually occurs with intransitive verbs: it turns the verb into a possessed noun that refers to the time that the event (described by the verb) took place. Examples of this suffix may be found in Table $4 \mathrm{~b}$ (line 2), and in Table $4 \mathrm{c}$ (lines 2 and 4).

For an extended discussion of all these forms, and many more, see Kockelman (2010, especially chapter 4$){ }^{*}$

* Manuscrit reçu en décembre 2015, accepté pour publication en octobre 2016.

This article is part of the Special issue Measures and textures of time among the Maya: the said, the written, and the lived.

Acknowledgements - This essay benefited greatly through comments and questions from Helen Siu, Jacob Welch, Paja Faudree, Stephen Houston, Oswaldo Chinchilla, Kay Warren, William Kelly, Scott AnderBois, Valentina Vapnarsky and an anonymous reviewer. Thank you.

\section{References cited}

Austin John

2003 How to Do Things with Words, Harvard University Press, Cambridge.

BENJAMIN Walter

1968 "The Work of Art in the Age of Mechanical Reproduction", in Hannah Arendt (ed.), Illuminations, Schocken Books, New York, p. 217-252.

Bull William E.

1960 Time, Tense, and the Verb: A Study in Theoretical and Applied Linguistics, With Particular Attention to Spanish, University of California Press, Berkeley.

Carlsen R.S. and M. Prechtel

1991 "The Flowering of the Dead: An Interpretation of Highland Maya Culture", Man, 26 (1), p. 23-42.

HeIDEGGER Martin

1996 [1927] Being and Time, trans. Joan Stambaugh, SUNY University Press, Albany. 
HuSSERL Edmund

1999 "Phenomenology of Internal Time Consciousness", in D. Welton (ed.), The Essential Husserl, Indiana University Press, Bloomington, p. 231-245.

JAKOBSON Roman

1990 "The Speech Event and the Functions of Language", in L. R. Waugh and Monica Monville-Burston (eds.), On Language, Harvard University Press,

JAMES William

Cambridge, p. 69-79.

1975 "The Experience of Time", in C. M. Sherover (ed.), The Human Experience of Time: The Development of its Philosophical Meaning, New York University Press, New York, p. 367-386.

Kockelman Paul

2010 Language, Culture, and Mind: Natural Constructions and Social Kinds, Cambridge University Press, Cambridge.

2015 "Four Theories of Things: Aristotle, Marx, Heidegger, and Peirce", Signs in Society, 3 (1), p. 153-192.

2016 The Chicken and the Quetzal: Incommensurate Ontologies and Portable Values in Guatemala's Cloud Forest, Duke University Press, Durham.

Kockelman Paul and Anya Bernstein

2012 "Semiotic Technologies, Temporal Reckoning, and the Portability of Meaning: Or, Modern Modes of Temporality-Just How 'Abstract' are They?",

MARx Karl Anthropological Theory, 12 (3), p. 320-348.

1967 [1867] Capital, International Publishers, New York.

MondLoch J.L.

1980 “K'e?s: Quiche Naming”, Journal of Mayan Linguistics, 2, p. 9-25.

SERRES Michel

2007 [1980] The Parasite, University of Minnesota Press, Minneapolis.

WILK Richard R.

1991 Household Ecology: Economic Change and Domestic Life among the Kekchi Maya in Belize, University of Arizona Press, Tucson. 